\title{
Hallusinosis due to methylphenidate overdose in an eight-year-old child: a case report
}

\author{
Sekiz yaşında bir çocukta metilfenidat doz aşımı ile oluşan halüsinoz: bir olgu sunumu
}

Ender ATABAY, Ayşe RODOPMAN ARMAN

\begin{abstract}
Methylphenidate, which blocks the presynaptic norepinephrine and dopamine transporters, is the most common used medication and offered as first choice in the treatment guidelines of attention deficit hyperactivity disorder (ADHD). One of its rarely seen adverse effects is, hallucinations that can be formed idiosyncratically, which can be correlated with increased dopaminergic functioning in synaptic cleft. We will present an eight year old boy diagnosed with ADHD-combined type, and oppositional defiant disorder (ODD) with no previous medical and family history who has impulsively taken extra dose of methylphenidate in the course of usual drug treatment. The acute hallucinosis presentation which has subsided the next day completely with the cessation of drug treatment will be discussed.
\end{abstract}

Keywords: Methylphenidate, Hallucinosis, Attention deficit hyperactive disorder

\section{ÖZ}

Presinaptik norepinefrin ve dopamin taşıyıcılarını bloke eden metilfenidat, dikkat eksikliği hiperaktivite bozukluğu (DEHB) tedavisinde en sık kullanılan ve tedavi rehberlerinde birinci tercih olarak sunulan ilaçtır. Nadir karşılaşılan yan etkilerinden biri de, sinaptik aralıktaki artmış dopaminerjik işleyiş ile ilişkilendirilen, idiosenkratik oluşabilen varsanılardır. Polikliniğimizde DEHBbileşik tip ve karşıt olma karşı gelme bozukluğu (KOKGB) teşhisi konularak metilfenidat tedavisine başladığımız, özgeçmiş ve soygeçmişinde herhangi bir hastalık öyküsü bulunmayan sekiz yaşındaki erkek bir çocukta, olağan ilaç tedavisi sırasında impulsif bir şekilde aldığı fazladan bir doz kısa etkili metilfenidat ile gelişen ve ilacın kesilmesiyle birlikte ertesi gün tümüyle gerileyen halüsinoz tablosunu tartışacağız.

Anahtar kelimeler: Metilfenidat, Halüsinoz, Dikkat eksikliği hiperaktivite bozukluğu

Ender Atabay ( $\square$ ), Ayşe Rodopman Arman

Department of Child and Adolescent Psychiatry, School of Medicine, Marmara University Hospital, Pendik, Istanbul, Turkey

e-mail:kubrend@yahoo.com

Submitted/Gönderme: 12.07 .2016

Accepted/Kabul: 22.08.2016

\section{Introduction}

Attention deficit hyperactivity disorder (ADHD) is one of the most common neurodevelopmental disorder in school age children. It is a heterogeneous disorder which is composed of core symptoms including hyperactivity, attention deficit and impulsivity. Short and long acting methylphenidate (MPH), amphetamine, mixed amphetamine salts, and atomoxetine are utilized for the pharmacologic treatment [1]. Methylphenidate is the most commonly used agent and it is the first option in treatment. MPH acts via specifically blocking presynaptic norepinephrine and dopamine transporters, impedes their reuptake thereby increases their levels in synaptic cleft $[2,3]$. MPH is safely used in children, adolescents and adults due to its low adverse effect profile. Among the most common adverse effects; sleeplessness, stomachache, headache, loss of appetite, irritability and anxiety can be considered. Relatively less commonly, tics and emotional fluctuations also can be seen [4]. In addition, in 1971 Lucas and Weiss, mentioned short lasting psychotic symptoms in patients who utilize methylphenidate [5]. In the current literature, "hallucinosis" and "toxicosis" terms are particularly used in order to differentiate temporary symptoms related to stimulants in contrast to permanent psychotic symptoms that are seen in schizophrenia and bipolar disorder [6]. Hallucinosis is described as the presence of complex auditory or visionary halucinations with preserved insight. There are no delusions or altered consciousness and temporarily it is defined as "pseudohallucinations" [7]. In literature, occurrence of hallucinations are considered as the end result of commonly high dose oral methylphenidate usage besides parenterally usage [8]. It is designated that this explicit mental state is short lasting, generally limits itself within a few hours and its possible ethiopathogenesis is chiefly related with increase in concentration of synaptic 
dopamine [4]. This presentation could be observed even after the first or low dose methylphenidate ingestion and idiosyncratic mechanisms have been speculated [3]. If abrupt pyschosis symptoms are observed as adverse effects of stimulants used for ADHD treatment, then the cessation of stimulant treatment and switching to atomoxetine treatment is recommended [9]. In this article, an eight year old male child patient who had hallucinosis after an overdose during regular MPH usage with therapeutic dosages is presented.

\section{Case Report}

An eight year old male patient, referred to Marmara University Faculty of Medicine, Child and Adolescent Psychiatry Outpatient Clinic by his teacher because of his "disobedience to rules, overactivity, irritability, attention deficit and academic underachievement" symptoms. According to clinical history obtained from his mother and father, he is always overactive, inpatient and generally he does not have anger management problems and he never gets to a point of harming another person. He was born with normal delivery from a first degree inter marriage (with cousin), in a hospital without any complications. There are no significant characteristics in his developmental background. His speech development and walking are within expected age range. There is no psychiatric disorder mentioned in his family and close relatives.

During detailed psychiatric examination, he made eye contact but looked out of the window frequently and he was constantly moving. In mental status examination, his place, time and person orientation was normal. He was easily distractible and it is hard for him to concentrate on interview. His mood was euthymic and affect was appropriate with his mood. His thought content was congruent with his age and affect. Any perception defect has not been defined. There was not any anxious and behavioral symptoms. He did not describe any problems with falling asleep or sleep maintenance. His appetite was normal. His speech was fast but comprehensible and logical. Generally he was responding without waiting for the end of the question.

He was reading the material syllable by syllable by following with his finger. He often omitted and added letters and confused letters by mistake. Also while he was writing although he was very slow and cautious, still he did more misspelling than expected according to his age. His right and left discrimination was developed.

As a result of the interview which is examined according to The Diagnostic and Statistical Manual of Mental Disorders
(DSM-4-TR) criteria, the patient was diagnosed with ADHD-combined type oppositional defiant disorder (ODD). Hemogram, biochemical tests and electrocardiography were planned as pretreatment evaluation. Due to the lack of episodic symptoms, pediatric neurology consultation and electroencephalography were not ordered. For possible learning disability co-occurrence, Weschsler Intelligence Scale for Children-revised (WISC-R) was planned.

After his examinations short acting methylphenidate medication was given first as $5 \mathrm{mg}$ in the morning and $5 \mathrm{mg}$ at noon. The dosage was gradually increased with the absence of any adverse effect, as $10 \mathrm{mg}$ in the morning and $10 \mathrm{mg}$ at noon, total $20 \mathrm{mg}$ /day was reached. For oppositional defiant behaviors, behavioral advices were given to the parents. When the patient admitted for next appointment his parents stated that their son's symptoms were decreased after the medication and his teacher was also glad. Soon after the dosage increase, they mentioned that they had an unusual situation in a night. The patient told his doctor that the medicine worked well and he wanted more. This acute state occurred after the patient ingested extra dose of two $10 \mathrm{mg}$ short acting MPH without his parents' knowledge at nighttime. As the parents estimated, 2 hours after the ingestion of medicine, he described the sounds of meowing and screaming cats in the kitchen; auditory and visual hallucinations like footsteps from outside. $\mathrm{He}$ mentioned that everything was moving and when his father came the cats suddenly escaped. In that particular time, he did not show any fear or anxiety symptoms. That night he could not fall asleep till morning and had a short restless sleep. When he woke up in the morning, there were no symptoms. After this event, his parents ceased the drug. When the patient came to his follow-up appointment, there was not any psychotic symptoms. The parents were highly worried and did not want to continue to use the medication. WISC-R examination revealed as subscores of verbal intelligence: 96, performance intelligence: 99 and total intelligence: 97 . Those scores were interpreted as within the normal intellectual range. The subscores of WISC-R did not support learning disability (LD).

\section{Discussion}

In our case report, we present an eight year old boy patient who experienced hallucinosis after impulsively taking an extra dose of short acting MPH. Although it is considered that the presence of hallucinations and psychosis are used as alternative explanations, in children this relation is 
rarely observed together. For the differential diagnosis, developmental stage of the child, the presence of any neurological disorder, stressful life events, cultural belief factors such as the effect of witches, ghosts and other spiritual beliefs, any other pscyhiatric disorder, medical conditions and overdose drug ingestion as our patient committed should be considered [10].

There are many cases who experienced abrupt psychotic features which is related to MPH usage in literature [11]. At therapeutic dosages of stimulants, frequency of psychotic symptoms is around $0.25 \%$ [9]. Seeing snakes, flies, cockroaches, mice, and meowing cats as our case presented and vivid hallucination themes are commonly encountered [11]. The time period of the appearance of hallucinations which defined as commonly sensorial and the ingestion of MPH may differ person to person [7,11]. Short lasting and self- limited psychotic features after ingesting extra doses of stimulants can be experienced independently from current psychological state of people [8]. It is claimed that stimulants that are taken above the therapeutic doses cause visual stimulation that can be perceived diversely due to the mechanism of the increased norepinephrine in lateral geniculate nucleus resulting an accelerated visual information flow [3]. These experiences mostly subside following the cessation of the medication like in our patient [10]. Carkaxhıu and colleagues, reported a retrospective review study of 60 stimulant-induced psychosis cases and in only $5 \%$ of them the symptoms were continuing despite the cessation of medication [4]. During the follow-up of our patient, there were not any psychotic signs and symptoms observed.

Dose-response relationship is well-defined in MPH treatment and with relatively higher doses. Better clinical responses in the presence of higher adverse effects are observed during the treatment. It is observed that therapeutic effects and serum concentrations of fast releasing MPH run parallel to each other and most of the symptomatic remission occurs within 1,5-2 hours after taking the medication $[4,12,13]$. And that time period was concordant with the beginning of the hallucinosis in our patient. Personal response differences for MPH is considered as a result of individualized dopamine and/or norepinephrine system responses [11]. Dopamine system consists of two main ascending systems. The first one starts from the substantia nigra and ends at striatum and includes nigrostriatal system that is composed of caudate nucleus and putamen. The other one is the mesocorticolimbic pathway which receives dopaminergic inputs from mesencephalon
[14]. The most specific regions that MPH binds are the terminal regions of nigrostriatal and mesolimbic pathways. These dopaminergic structures are also responsible for the effect of medications [15]. The relation between dopamine and psychotic presentation is also well-defined. Dopamine which is found in high levels in limbic system is accepted as having a key role in hallucination formation [10].

In an investigation study of amphetamine triggered psychosis cases, the importance of dopaminergic effect in central nervous system is emphasized. It is stated that there might be a personal predisposition for over production of dopamine receptor subtype 2 (DRD2) which may lead to over-production of DRD2 [16].

Clinical studies offer a personal difference in response to stimulant treatment independent from the factors like age, weight and drug metabolism. Some of these differences are explained with phenotypic differences like healthy volunteers, the ones who abuse drugs and the patients diagnosed as ADHD [12,17]. The monitorization study which is conducted by positron emission tomography (PET) revealed that dopaminergic changes in brain may have huge personal variety [18]. Because of polymorphism of carboxylesterase 1 enzyme which metabolize MPH primarily, MPH rises to unexpected high doses [17,19]. Although it is not clearly denoted as psychosis, another group which is prone to stimulants' adverse effects is the group who has neurodevelopmental disorders like mental retardation and autism [13]. In our patient, there was not any developmental disorder explained that might cause hypersensitivity to adverse effects of stimulants. Despite the absence of a particular etiologic factor that could explain the hallucinosis in our case, it is considered to be caused by individualized over reaction of dopaminergic pathways to acute MPH stimulation

Psychotic perception experiences with MPH can be very worrying for both child and the family although it is seen rarely. At the same time, it is clear that this situation will be a milestone for treatment continuity in family, children and doctor. Being cautious is highly important for the clinicians for this rarely seen adverse effect of MPH. With our patient's own explanation for ingesting over dose of MPH for the sake of "a better treatment", it should bring to our mind that a patient can easily ingest the medication with an impulsive behavior thinking that taking higher doses of MPH will lead to a better therapeutic response. 


\section{References}

1. Hodgkins P, Shaw M, Coghill D, et al. Amphetamine and methylphenidate medications for attention deficit/ hyperactivity disorder: complementary treatment options. Eur Child Adolesc Psychiatry 2012; 21:477-92. doi: 10.1007/ s00787-012-0286-5

2. Stahl M S. Stahl'ın Temel Psikofarmakolojisi. 4.Baskı. Alkın T, çeviri editörü. İstanbul:İstanbul Tıp Kitabevi, 2015; 490-7.

3. Hesapçığlu ST, Göker Z, Bilginer Ç, et al. Methylphenidate induced psychotic symptoms: two cases report. J Med Cases 2013; 4:106-8. doi: http://dx.doi.org/10.4021/jmc923w

4. Carkaxhıu G, Yılmaz S, Sabuncuoğlu O. Stimulant related psychosis in ADHD treatment: an update for past 10 years. Curr Psychopharmacol 2013; 2:218-21. doi: 10.2174/22115560113029990005

5. Lucas AR, Weiss M. Methylphenidate hallucinosis. JAMA 1971;217:1079-81. doi:10.1001/jama.1971.03190080041008

6. Ross GR. Psychotic and manic-like symptoms during stimulant treatment of attention deficit hypractivity disorder. Am J Psychiatry 2006; 163:1149-52. doi:10.1176/appi. ajp.163.7.1149

7. Bell V, Raballo A, Laroi F. Assessment of hallucinations. In: Laroi F, Aleman A, editors. Hallucinations: A Guide to Treatment and Management. Chapter 19. Oxford:Oxford University Press, 2010; 389-90.

8. Abalı O, Mukaddes NM. Metilfenidat tedavisi ile ortaya çıkan varsanılar: olgu sunumu. Klin Psikofarmakol B 2007; 17:195-7.

9. Rittmannsberger H, Christian F, Holler M. Methylphenidate for psychosis and aggression in a patient comorbid with ADHD - A case report. Psychiat Danub 2014; 26:77-9.

10. Sldhu K, Dickey T. Hallucinations in children: Diagnosis and treatment strategies. Curr Psychiatry 2010; 9:53-61.

11. Goetz M, Prihodova I, Hrdlıcka M. Long lasting complex nocturnal hallucinations during osmotic release oral system (OROS) methylphenidat treatment in a 7 year old girl. Neuro Endocrinol Lett 2011; 32:619-22.
12. Volkow N, Swanson J. Variables that affect the clinical use and abuse of methylphenidate in the treatment of ADHD. Am J Psychiatry 2003; 160:1909-18. doi:http://dx.doi. org/10.1176/appi.ajp.160.11.1909

13. Pearson D, Lane D, Santos C, et al. Effects of methylphenidate treatment in children with mental retardation and ADHD: individual variation in medication response. J Am Acad Child Adolesc Psychiatry 2004; 43:686-98. doi:10.1097/01. chi.0000120024.14101.96

14. Vles JSH, Feron FJM, Hendriksen JGM, et al. Methylphenidate down-regulates the dopamine receptor and transporter system in children with attention deficit hyperkinetic disorder (ADHD). Neuropediatrics 2003; 34:7780. doi: 10.1055/s-2003-39602

15. Engert V, Pruessner CJ. Dopaminergic and noradrenergic contributions to functionality in ADHD: The role of methylphenidate. Curr Neuropharmacol 2008; 6:322-8. doi:10.2174/157015908787386069

16. Bramness JG, Gundersen QH, Guterstam J, et al. Amphetamine-induced psychosis - a separate diagnostic entity or primary psychosis triggered in the vulnerable? BMC Psychiatry 2012; 12:221. doi: 10.1186/1471-244X-12-221

17. Nevels RM, Weiss NH, Killebrew AE, et al. Methylphenidate and its under-recognised, under-explained and serious drug interactions: A review of the literature with heightened concerns. German J Psychiatry 2013; 16:29-42.

18. Volkow N, Wang GJ, Fowler JS, et al. Relationship between blockade of dopamine transporters by oral methylphenidat and the increases in extracellular dopamine: therapeutic implications. Synapse 2002; 43:181-7. doi:10.1002/ syn. 10038

19. Zhu HJ, Patrick KS, Yuan HJ, et al. Two CES1 gene mutations lead to dysfunctional carboxylesterase 1 activity in man: clinical significance and molecular basis. Am J Hum Genet 2008; 82: 1241-8. doi: 10.1016/j.ajhg.2008.04.015 